\title{
Проблемні аспекти ведення лісового господарства на землях оборони
}

\author{
Олексій Чернецький * А; Анна Чернецька ${ }^{\text {B }}$ \\ А Територіальне управління внутрішнього аудиту військових частин, безпосередньо підпорядкованих Міністерству оборони України та \\ Генеральному штабу збройних Сил України, 6,Повітрофлотський проспект, м. Київ-168, 03168, Україна \\ в Військовий інститут Київського Національного Університету імені Т. Шевченка, вул. Михайла Ломоносова, 81, м. Київ, 03680, Україна
}

Received: August 2, 2020 | Revised: August 20, 2020 | Accepted: August 31, 2020

DOI: $10.33445 /$ sds.2020.10.4.7

\begin{abstract}
Анотація
В статті розглянуто історичні аспекти та сучасний стан ведення лісового господарства на землях, наданих для потреб оборони. Досліджено проблематику організації ведення лісового господарства суб'єктами лісогосподарської діяльності, органом управління яких $€$ Міністерство оборони України.

Проведений автором статті аналіз дозволив йому дійти висновку про те, що з 1991 року постійно змінювалась і перекручувалась основна мета створення та функціонування у сфері оборонного відомства лісогосподарських підрозділів. На момент створення у 1949 році військові лісгоспи забезпечували організацію ведення взірцевого лісового господарства та відтворення лісів на землях оборони навколо військових аеродромів, полігонів, арсеналів тощо. Натомість, на цей час основна мета діяльності лісогосподарських суб'єктів господарювання, органом управління яких є Міністерство оборони України, була зведена до отримання прибутку. Крім того, зловживання посадовими особами різних рівнів та бездіяльність оборонного відомства, як органу управління майном, призвели до безпідставного відчуження земельних ділянок та засобів виробництва, якими лісогосподарські підрозділи наділялись при створенні та в процесі функціонування. Безпідставність відчуження майна лісогосподарських підрозділів оборонного відомства, на думку автора, зумовлена особливим статусом майна військових лісгоспів. Аналіз національного законодавства засвідчив, що з набутяям Україною незалежності майно установ і організацій, які увійшли до складу збройних Сил України набуло статусу військового майна. Отже, відчуження такого майна неможливе без прийняття урядом України відповідних рішень.

Також, на думку автора, в реаліях сьогодення ведення лісового господарства на землях оборони має бути організовано неприбутковими лісогосподарськими підрозділами зі сфери управління Міністерства оборони України.
\end{abstract}

Ключові слова: лісове господарство, землі оборони, державне підприємство, ефективність лісокористування, державний контроль, ліси оборони, військове майно.

\section{Постановка проблеми}

Лісове господарство $€$ важливою складовою економіки України та принципово важливим не тільки 3 економічної, а й 3 екологічної точки зору. Недбале i неефективне ведення останнього може спричинити не тільки настання економічних (втрата державних активів, збитки від розкрадання та неефективного управління тощо), а й екологічних (повені, завдання непоправних наслідків для екосистем відповідних регіонів тощо) наслідків. Крім того, незадовільна організація лісового

\footnotetext{
* Corresponding author: Територіальне управління внутрішнього аудиту військових частин, безпосередньо підпорядкованих Міністерству оборони України та Генеральному штабу Збройних Сил України, старший офіцер, e-mail: oleksiy.chernetskyi81@ukr.net
} 
господарства та відсутність належного державного контролю за його веденням можуть спричинити підвищення активності кримінальних груп (в тому числі і міжнародних), які спеціалізуються на контрабанді ділової деревини під виглядом дров, що, в свою чергу, несе репутаційні ризики та створює напруженість у відносинах України із західними партнерами.

Так само як і в організації загальнодержавного лісового господарства, так і в організації лісового господарства на землях оборони, існують певні проблеми, пов'язані, насамперед 3 відсутністю нормативного врегулювання останнього. Як наслідок, відсутність чітких правил і єдиного підходу до ведення лісового господарства на землях оборони спричиняє зловживання 3 боку керівників як суб'єктів господарювання, так і органу управління майном.

\section{Аналіз останніх досліджень та публікацій}

Важливий внесок у дослідження проблем лісового господарства зробили такі вчені, як Ю.М. Барський [1], Х.П. Замула [2], О.О. Кахович [3], О.Р. Мазуренок [4], А.О. Мещерова [5] та інші. Проте, варто зазначити, що проблемам ведення лісового господарства саме на землях оборони не приділялось належної уваги і тому зазначене питання потребує більш детального дослідження.

\section{Постановка завдання}

Метою статті $€$ дослідження історичних аспектів та сучасного стану ведення лісового господарства на землях оборони України, визначення проблемних аспектів та шляхів їх вдосконалення для ефективного лісокористування в інтересах Міністерства оборони України і держави в цілому.

\section{Виклад основного матеріалу}

Відповідно до даних, наведених на офіційній сторінці Державного агентства лісових ресурсів (далі - Держлісагенство), загальна площа лісового фонду України становить 10,4 млн. га, із яких вкритих лісовою рослинністю - 9,6 млн. га. Переважна більшість лісів на території України є державними лісами, закріпленими за державними спеціалізованими підприємствами, функціональне управління якими покладено саме на Держлісагенство, яке $\epsilon$ основним органом виконавчої влади у сфері ведення лісового господарства та мисливства. Частина ж вкритих лісами територій (орієнтовно $20 \%$ загальної площі лісових ресурсів) у різні періоди надавались у постійне користування для виконання іншими міністерствами і відомствами своїх функцій. Одним 3 міністерств, яке використовує ліси для виконання покладених на нього функцій $\epsilon$ i Міністерство оборони України (орієнтовно $1 \%$ загальної площі лісових ресурсів). Розподіл загальної площі земель лісового фонду України за відомчою підпорядкованістю представлено на мал.

Якщо, у випадку з лісами Держлісагенства, які переважно виконують водоохоронні, санітарно-гігієнічні та оздоровчі функції, а також забезпечують потреби суспільства в лісових ресурсах, ліси оборони виконують функції, що характерні тільки для оборонного відомства.

Так, основними функціями лісів на землях оборони $€$ забезпечення функціонування військових частин та військових об'єктів, збереження озброєння, військової техніки, іншого військового майна, охорони державного кордону України, захисту населення, господарських об'єктів і довкілля від впливу аварійних ситуацій, стихійних лих і пожеж, що можуть виникнути на цих об'єктах. Неможливість застосування штатних одиниць техніки під час навчань, у разі відсутності лісів, негативно впливає на бойові спроможності підрозділів Збройних Сил України. Важливою функцією лісів на землях оборони, особливо в 
умовах збройної агресії Російської Федерації проти України, $€$ маскування військових об'єктів.



Мал. Розподіл загальної площі земель лісового фонду України за відомчою підпорядкованістю

Для більш чіткого розуміння призначення лісів, розташованих на землях оборони, необхідно проаналізувати документи, на підставі яких здійснювалось закріплення лісів за Міністерством оборони України та його правовими попередниками.

Так, первісне закріплення лісів, розташованих на землях оборони сучасної України, за оборонним відомством колишнього СРСР було здійснено на підставі Постанови Ради Міністрів СРСР від 19.04.1948 № 1264478 с “Про закріплення лісів за Міністерством 3бройних Сил СРСР". Згідно 3 цим документом за Міністерством Збройних Сил СРСР закріплювалися всі ліси, що знаходились на земельних ділянках, відведених під полігони, аеродроми, табори, навчальні поля, військові містечка, бази, склади та інші військові об'єкти та покладався обов'язок 3 “організації в закріплених лісах зразкового господарювання під загальним контролем Міністерства лісового господарства СРСР за узгодженим з ним планом".

Згідно з Порядком ведення лісового господарства в закріплених за Міністерством оборони СРСР лісах, затвердженим розпорядженням Ради Міністрів СРСР від 17.09.1965 № 1869PС, з метою забезпечення режиму секретності військових об'єктів, дислокованих в лісах, органи лісового господарства звільнялися від здійснення загального нагляду та контролю за веденням лісового господарства в даній категорії лісів. У зв'язку з цим Міністерство оборони СРСР повинно було посилити нагляд за веденням лісового господарства в закріплених за ним лісах та у разі необхідності створивши службу лісового господарства в центральному апараті Міністерства оборони та у відповідних військових округах.

Використання земель державного лісового фонду військові лісгоспи і військові частини здійснювали під контролем Міністерства сільського господарства СРСР і його територіальних органів. Військові лісгоспи допускали представників Міністерства сільського господарства СРСР і його органів в закріплені за ними ліси для перевірки стану лісу і ведення лісового господарства, а представників Міністерства фінансів СРСР і його органів - для перевірки правильності обчислення і збору лісового доходу, з відома відповідних начальників квартирно-експлуатаційних управлінь (далі КЕУ) військових округів і командирів дислокованих на території військового лісгоспу 3 оформленням допусків на перевірку (Директива Міністра оборони СРСР від 19.02.1955 № 02/125).

Так само як і на всій території СРСР, на території сучасної України було створено низку військових лісгоспів (лісництв) та ліспромкомбінатів, які разом з відділом лісового господарства та землекористування КЕУ Міністерства оборони СРСР, групами лісового господарства КЕУ військових округів і Головного інженерного управління Військово-Морського Флоту, здійснювали ведення лісового господарства на землях оборони.

Аналізуючи нормативно-правові документи, на підставі яких військові лісгоспи (військові лісництва) та ліспромкомбінати здійснювали діяльність, можна дійти висновку, що останні забезпечувались військовим майном відповідно до Норм комплектації технічним майном органів квартирно-експлуатаційної служби та лісового господарства Радянської Армії i Військово-Морського Флоту. Джерелом же 
фінансування видатків на утримання апарату служб лісового господарства, ведення лісового господарства, лісовпорядкування, охорону лісів та поточний ремонт будівель і споруд військових лісгоспів (військових лісництв) визначались кошти за кошторисом Міністерства оборони України та його правових попередників.

Таким чином, доходимо висновку, що військові лісгоспи (військові лісництва) створювались як структурні підрозділи військових Установ (КЕУ відповідних військових округів), наділялись військовим майном, фінансувались за рахунок оборонного відомства, а основною метою їх створення було саме ведення лісового господарства на землях оборони. Натомість, у період з 1991 року по цей час основна мета створення суб'єктів господарювання лісогосподарського комплексу Міністерства оборони України постійно перекручувалась, що спричинило завдання значної шкоди економічним інтересам оборонного відомства внаслідок порушення його прав як постійного лісокористувача на землях оборони. Крім того, численні зловживання посадовців різних рівнів призвели до виведення значних площ земельних ділянок, які надавались для розміщення і постійної діяльності військових частин, установ і організацій, зі сфери управління Міністерства оборони України.

Необхідно зазначити, що особливості охорони, захисту, використання та відтворення лісів на окремих категоріях земель визначено у главі 20 лкУ.

Так, статтею 101 лКУ визначено, що ліси, розташовані на землях оборони, призначені для розміщення і постійної діяльності військових частин, установ, військовонавчальних закладів, підприємств та організацій Збройних Сил України, інших військових формувань, утворених відповідно до закону. Охорона, захист, використання та відтворення лісів на землях оборони проводяться спеціалізованими лісогосподарськими підрозділами 3 урахуванням режиму цих територій в порядку, встановленому Законом № 1345-IV, ЛКУ та

\section{іншими актами законодавства.}

Згідно з частиною 1 статті 2 Закону № 1345IV військовим частинам для виконання покладених на них функцій та завдань надаються у постійне користування земельні ділянки, а частиною 4 статті 2 цього ж закону визначено, що військові частини зобов'язані використовувати надані їм земельні ділянки відповідно до вимог земельного і природоохоронного законодавства та 3 дотриманням вимог щодо забезпечення безпеки населення у процесі проведення ними постійної діяльності.

Якщо термін “ліси оборони” вводився ЛкУ лише у редакції Закону України "Про внесення змін до Лісового кодексу України" від 08.02.2006 № 3404-IV (набув чинності 29.03.2006), то термін “землі оборони" існував з часу набуття чинності Земельним Кодексом Української Радянської Соціалістичної Республіки від 18.12.1990 (далі - ЗК УРСР), який зберігав чинність до 01.01.2002.

Так, статтею 70 ЗК УРСР, землями для потреб оборони визнавались землі, надані для розміщення та постійної діяльності військових частин, установ, військовонавчальних закладів, підприємств і організацій Збройних Сил України, інших військових формувань та внутрішніх військ.

Виникнення ж права власності та права користування земельними ділянками регламентувались статтею 22 ЗК УРСР, відповідно до якої, право власності на землю або право користування наданою земельною ділянкою виникає після встановлення землевпорядними організаціями меж земельної ділянки в натурі (на місцевості) і одержання документа, що посвідчує це право.

Аналогічну норму містить і діючий Земельний Кодекс України, статтею 125 якого визначено, що право власності на земельну ділянку, а також право постійного користування та право оренди земельної ділянки виникають з моменту державної реєстрації цих прав. Першою ж редакцією статті 125 діючого ЗКУ визначалось, що право власності та право постійного користування 
на земельні ділянки виникає після одержання iï власником або користувачем документа, що посвідчує право власності чи право постійного користування земельною ділянкою, та його державної реєстрації.

Отже, проаналізувавши зміст норм наведених вище нормативно-правових актів можна зробити висновок, що на землі (в тому числі і вкриті лісами), які у різні періоди були надані у постійне користування установам і організаціям (КЕВ, КЕЧ, військові частини) Збройних Сил України та колишнього СРСР (які розташовані на території сучасної України), мали $б$ бути виготовлені правовстановлюючі документи, а використання їх мало б здійснюватись виключно в межах законодавства, в тому числі земельного і лісового. Крім того, на землях оборони вкритих лісами Міноборони мало б організувати ведення лісового господарства спеціалізованими лісогосподарськими підрозділами.

Неоформлення ж установами і організаціями Збройних Сил України (KEB, КЕЧ, військові частини) правовстановлюючих документів на виділені для потреб оборони земельні ділянки спричинили зловживання 3 боку посадовців як Міністерства оборони України, так і місцевих органів самоврядування та безпідставної зміни цільового призначення земель.

В період з 2003 по 2006 роки на земельні ділянки, виділені у різні періоди для потреб оборони, керівниками лісогосподарських підприємств Міністерства оборони України були оформлені правовстановлюючі документи на право постійного користування земельними ділянками з цільовим призначенням “для ведення лісового господарства”. Тобто, фактично відбулась безпідставна зміна цільового призначення земельних ділянок, що є порушенням норм статті 20 ЗКУ, якою визначено, що зміна цільового призначення земель провадиться органами виконавчої влади або органами місцевого самоврядування, які приймають рішення про передачу цих земель у власність або надання у користування.

слід підкреслити, що

власником земельних ділянок, закріплених за суб'єктами, що перебувають у сфері управління Міноборони, є держава в особі Кабінету Міністрів України, оскільки статтею 116 Конституції України саме Кабінет Міністрів України є вищим органом в системі органів виконавчої влади, якому надано повноваження 3 управління об'єктами державної власності. Аналогічна норма закріплена статтею 13 ЗКУ, відповідно до якої повноваження щодо розпорядження землями державної власності відноситься виключно до повноважень Кабінету Міністрів України в межах, встановлених кодексом.

Отже, виходячи з того, що землі оборони знаходяться у Міноборони лише в користуванні, а розпоряджається ними Кабінет Міністрів України (ст.13 Кодексу), то відповідно до статті 142 ЗКУ виключно Кабінет Міністрів України має право припиняти право користування земельною ділянкою, що входить до складу земель оборони, і інформувати про це місцеві органи виконавчої влади та органи місцевого самоврядування.

у різні періоди для потреб оборони, в користування установ і організацій збройних Сил України та Збройних Сил колишнього СРСР (військові частини, КЕВ та КЕЧ), були виділені земельні ділянки лісового фонду загальною площею орієнтовно 196,79 тис. га, з яких 153,0 тис. га вкритих лісами.

Право користування землею за установами і організаціями Збройних Сил України оформлено лише на земельні ділянки загальною площею 69,0 тис. га, що у відносних величинах складає приблизно 35 \% загальної площі земельних ділянок, виділених оборонному відомству з лісового фонду.

Державними лісогосподарськими підприємствами, органом управління яких $€$ Міністерство оборони України, безпідставно виготовлено правовстановлюючі документи зі зміною цільового призначення 3 земель оборони на землі для ведення лісового господарства на земельні ділянки загальною площею орієнтовно 42,0 тис. га, що у відносних величинах складає приблизно 21 \% загальної 
площі земельних ділянок, виділених оборонному відомству з лісового фонду.

Разом з тим, у нашому випадку Кабінетом Міністрів України не приймались рішення про зміну цільового призначення земельних ділянок 3 "земель оборони" на "землі для ведення лісового господарства", що підтверджує безпідставність такої зміни.

Оформлення лісогосподарськими суб'єктів господарювання Міноборони державних актів на земельні ділянки 3 цільовим призначенням "ведення лісового господарства", а також не оформлення правовстановлюючих документів на земельні ділянки відповідними КЕЧ (KEB) районів, не тільки спричинило безпідставну зміну цільового призначення земельних ділянок, які надавались для потреб оборони і мали статус "земель оборони", а і стало причиною безпідставного відчуження цих земельних ділянок та створення ризиків подальшої втрати земель оборони. Зазначене суперечить вимогам ЗКУ та спричиняє підрив бойової готовності військ та обороноздатності країни в цілому, оскільки, як зазначалось вище, ліси оборони є важливим елементом оборони та маскування військових об'єктів, захисту цивільного населення від результатів виникнення позаштатних ситуацій на цих об'єктах.

Крім того, відповідно до пункту в) частини 1 статті 95 ЗКУ, землекористувачі мають право використовувати у встановленому порядку для власних потреб наявні на земельній ділянці загальнопоширені корисні копалини, торф, ліси, водні об'єкти, а також інші корисні властивості землі.

Така сама норма закріплена і ЛКУ. Так, частиною четвертою статті 17 ЛкУ визначено, що право постійного користування лісами посвідчується державним актом на право постійного користування земельною ділянкою.

Враховуючи викладене доходимо висновку, що право користування лісами, які знаходяться на земельних ділянках, наданих у постійне користування установам і організаціям Міністерства оборони України належить цим установам і організаціям оборонного відомства, а не комерційні підприємства, правовий статус яких на цей час не врегульовано.

Так, якщо право землекористування (оформлені правовстановлюючі документи на земельну ділянку) належить тій чи іншій квартирно-експлуатаційній частині району, або військовій частині, то саме ця квартирноексплуатаційна частина, або військова частина і $\epsilon$ постійним лісокористувачем на відповідній земельній ділянці. Як наслідок, беручи до уваги ЛКУ і ЗКУ, саме ці установи і організації мають виключне право користуватись лісами та іншими загальноприйнятими корисними копалинами, які розташовані на земельних ділянках, де останні $\epsilon$ постійними землекористувачами.

Отже, окрім збитків через виведення земельних ділянок зі сфери управління Міноборони, Збройним Силам України також щорічно завдаються збитки внаслідок втрати установами і організаціями останніх лісопродукції, заготовленої комерційними підприємствами у лісах, розташованих на землях оборони.

За підрахунками автора, враховуючи нормативний щорічний приріст деревини 3 одного гектару лісу (3,5-4 м²/га), в результаті зміни цільового призначення земельних ділянок, наданих для потреб оборони, установи і організації Збройних Сил України, для потреб яких у різні періоди виділялись ці земельні ділянки, щорічно втрачають орієнтовно від 147000 до $168000 \mathrm{~m}^{3}$ лісопродукції $\quad\left(3,5 \cdot 42000=147000 \quad \mathrm{M}^{3}\right.$; 4,0·42000=168 $\left.000 \mathrm{~m}^{3}\right)$.

Також необхідно підкреслити про неврегульованість ведення лісового господарства на землях оборони. Так, у період з 1991 року по 21.07.1997 Міноборони користувалось наказом Міністра оборони колишнього СРСР від 08.07.1966 № 161, а після цієї дати - двічі видавало накази, якими затверджувались положення про ведення лісового господарства на землях оборони (положення, затверджені наказами Міністра оборони України від 21.01.1997 № 22 та від 28.07.2011 № 458). Однак, у грудні 2011 року наказ Міністра оборони України від 
28.07.2011 № 458 був скасований, а отже, i були скасовані і положення, які ним вводились в дію.

Таким чином, 3 грудня 2011 року в Міноборони відсутній порядок ведення лісового господарства на землях оборони, що не могло не позначитись на фінансовогосподарській діяльності лісогосподарських підприємств оборонного сектору.

Необхідно відмітити, що нормами, закріпленими Законом № 1934, Збройні Сили України $\epsilon-$ військовим формуванням, на яке відповідно до Конституції України покладаються завдання з оборони України, захист їі суверенітету, територіальної цілісності та недоторканності.

Для виконання покладених на Збройні Сили України завдань та постійної дислокації їх структурних підрозділів (військові частини, установи і організації) останні наділялись земельними ділянками для потреб оборони (в тому числі і вкритих лісом), порядок використання яких визначено нормами Закону № 1345-IV.

Нормами ж ЛКУ визначено необхідність створення в оборонному відомстві спеціалізованих лісогосподарських підрозділів для забезпечення ведення на землях оборони вкритих лісом (ліси оборони) лісового господарства з урахуванням норм Закону № 1345-IV.

Разом з тим, статтею 4 Закону № 1345-IV визначено, що військові частини за погодженням 3 органами місцевого самоврядування або місцевими органами виконавчої влади і в порядку, визначеному Кабінетом Міністрів України, можуть дозволяти фізичним і юридичним особам вирощувати сільськогосподарські культури, випасати худобу та заготовляти сіно на землях, наданих їм у постійне користування. Слід зазначити, що на даний час такого порядку Кабінетом Міністрів України не розроблено.

Більше того, аналіз змісту статті 4 Закону № 1345-IV дозволяє зробити висновок, що єдиною комерційною діяльністю, яка теоретично можлива на землях, наданих у постійне користування Збройним Силам
України, $€$ сільське господарство. Однак, лісове господарство - це відмінний від сільського господарства вид комерційної господарської діяльності. Таким чином, комерційна лісогосподарська діяльність на землях оборони лісогосподарських підприємств перебуває поза межами правового поля з означеного питання.

На думку автора, ведення лісового господарства на землях, наданих для потреб оборони, має здійснювати некомерційна державна установа, основною метою створення якої має бути догляд за лісами, які зростають на землях оборони. Зазначене ґрунтується на аналізі норм ЛКУ та інших нормативно-правових актів, які регламентують як лісогосподарську діяльність, так і господарську діяльність в цілому.

Так, статтею 2 ЛКУ визначено, що лісові відносини - суспільні відносини, які стосуються володіння, користування та розпоряджання лісами і спрямовуються на забезпечення охорони, відтворення та стале використання лісових ресурсів, з урахуванням екологічних, економічних, соціальних та інших інтересів суспільства.

Статтею 101 лкУ визначена необхідність створення спеціалізованих лісогосподарських підрозділів для ведення лісового господарства в лісах оборони з урахуванням норм Закону № 1345-IV, який не дозволяє здійснення на землях оборони ніякої господарської діяльності, окрім сільськогосподарської діяльності.

Оскільки основною метою створення будьяких комерційних суб'єктів господарювання $\epsilon$ отримання прибутку, то і здійснення ними діяльності на землях оборони мало 6 передбачати отримання прибутку від такої діяльності. Разом 3 тим, імперативною нормою Закону № 1345-IV лісогосподарська діяльність на землях оборони заборонена, тим більше господарська діяльність, метою якої $є$ отримання прибутку.

Враховуючи викладене доходимо висновку, що основною метою функціонування лісогосподарських підрозділів в оборонному відомстві має бути здійснення комплексу заходів з охорони, захисту, 
раціонального використання та розширеного відтворення лісів задля забезпечення інтересів суспільства 3 надання Державою гарантій захисту конституційних прав і свобод громадян (спроможність ЗСУ захистити суверенітет і територіальну цілісність держави і гарантувати безпеку цивільного населення у воєнний і мирний час), а не отримання прибутку від такої діяльності.

Натомість, в Міноборони, починаючи 3 1993 року, на базі структурних підрозділів КЕУ (KЕВ) військових округів, були створені комерційні лісогосподарські підприємства, які фактично позбавили установи і організації Збройних Сил України, які у різні часи наділялись земельними ділянками для потреб оборони, переважного права використовувати у встановленому порядку для власних потреб наявні на земельній ділянці загальнопоширені корисні копалини, торф, ліси, водні об'єкти, а також інші корисні властивості землі.

Автором проаналізовано різноманітні моделі ведення лісового господарства на землях оборони, які використовуються у світовій практиці.

Наприклад, у Сполучених Штатах Америки ведення лісового господарства У

\section{Висновки}

У статті розглянуто історичні аспекти та сучасний стан системи ведення лісового господарства на землях оборони України. Результати дослідження засвідчили нагальну необхідність їі реформування. Нормативноправова неврегульованість зазначеного питання спричинила завдання шкоди економічним та іншим інтересам оборонного відомства.

На думку автора, для організації ведення лісового господарства оборонному відомству України доцільно було б використовувати некомерційні установи у його системі. федеральних лісах, до яких відносяться і ліси оборони, здійснюється незалежними підрядниками, які виграють аукціони i отримують право укладати контракти.

у Російській Федерації та Республіці Білорусь ліси оборони виведені із загального лісового фонду, а ведення лісового господарства на цих землях здійснюється некомерційними установами оборонних відомств.

Так, ведення лісового господарства на землях оборони Російської Федерації здійснюється Федеральною державною казенною установою "Управління лісового господарства та природокористування" Міністерства оборони Російської Федерації.

Ліси, розташовані на землях оборони та безпеки, закріплені за Міноборони Росії відповідно до постанови Уряду Російської Федерації від 02.02.1998 № 135 “Про закріплення лісів, розташованих на землях оборони, за федеральним органом виконавчої влади 3 питань оборони". Відповідно до зазначеної постанови, ліси, розташовані на землях оборони, виключені зі складу лісового фонду і надані Міноборони Росії з метою забезпечення потреб збройних Сил Російської Федерації.

\section{Список використаних джерел}

1. Барський Ю., Поліщук В. Фінансове стимулювання сталого розвитку лісового господарства регіонів України.
Реалізація цієї стратегії дозволить не лише мінімізувати ризики втрати державного майна, яке фактично є військовим майном, але й мінімізує витрати 3 державного бюджету на закупівлю і виготовлення виробів 3 деревини (меблів, дверей, приліжкових тумб, пірамід для зброї тощо) для потреб Збройних Сил України, оскільки ці вироби можливо буде виготовляти 3 власної давальницької сировини як в рамках оборонного відомства, так і на приватних деревообробних підприємствах. 
2. Замула Х. Сучасний стан ведення лісового господарства в Україні. Агросвіт. 2013. № 19. C. 54 - 59. URL: http://nbuv/gov.ua/ UJRN/agrosvit_2013_19_12.

3. Кахович О., Тюленева Г. Лісове господарство. Актуальні проблеми галузі та шляхи їх вирішення. URL: http://rusnauka.com/21_NIEK_2007/Econo mics/24123/doc.htm

4. Мазуренок О. Економічне значення лісів України та стратегія їх ефективного розвитку. Науковий вісник Херсонського державного університету. 2014. Вип. 5. С. $209-212$.

5. Мещерова А. Сучасний стан лісового господарства України. Проблеми та перспективи розвитку. URL: http://rusnauka.com/17_AND_2010/ Economics/68627.doc.htm.

6. Положення про квартирно-експлуатаційну службу і квартирне постачання Радянської Армії і Військово-Морського Флоту, затвердженого наказом Міністра оборони СРСР від 22.02.1977 № 75.

7. Положення про ведення лісового господарства та Положення про служби лісового господарства Міністерства оборони України, затверджені наказом Міністра оборони України від 21.01.1997 № 22.
8. Постанова Ради Міністрів СРСР “Про закріплення лісів за Міністерством Збройних Сил СРСР" від 19.04.1948 № 1264478 c.

9. Порядок ведення лісового господарства в закріплених за Міністерством оборони СРСР лісах, затвердженим розпорядженням Ради Міністрів СРСР від 17.09.1965 № $1869 \mathrm{PC}$.

10. Про використання земель оборони: Закон України від 27 листопада 2003 р. № 1345IV.

11. Лісовий кодекс України, введений в дію Постановою Верховної Ради України від 21.01.1994 № 3853-XI.

12. Земельний Кодекс Української Радянської Соціалістичної Республіки від 18.12.1990.

13. Положення про порядок ведення лісового господарства в лісах, закріплених за Міністерством оборони СРСР, і Положення про органи лісового господарства Міністерства оборони СРСР, ззатверджені наказом Міністра оборони СРСР від 08.07.1966 № 161;

14. Постанова Уряду Російської Федерації від 02.02.1998 № 135 “Про закріплення лісів, розташованих на землях оборони, за федеральним органом виконавчої влади 3 питань оборони".

\title{
Проблемные аспекты ведения лесного хозяйства на землях обороны
}

\begin{abstract}
Алексей Чернецкий * А; Анна Чернецкая ${ }^{\mathrm{B}}$
*Corresponding author: Территориальное управление внутреннего аудита воинских частей, непосредственно подчиненных Министерству обороны Украины и Генеральному штабу Вооруженных Сил Украины, старший офицер, e-mail: oleksiy.chernetskyi81@ukr.net

А Территориальное управление внутреннего аудита воинских частей, непосредственно подчиненных Министерству обороны Украины и Генеральному штабу Вооруженных Сил Украины, проспект Воздухофлотский, 6, г. Киев-168, 03168, Украина

в Военный институт Киевского Национального Университета имени Тараса Шевченко, ул. Михаила Ломоносова, 81, г. Киев, 03680, Украина
\end{abstract} Аннотация

В статье рассмотрены исторические аспекты и современное состояние ведения лесного хозяйства на землях, предоставленных для нужд обороны. Исследована проблематика организации ведения лесного хозяйства субъектами лесохозяйственной деятельности, органом управления которых является Министерство обороны Украины.

Проведенный автором статьи анализ позволил ему сделать вывод о том, что с 1991 года постоянно менялась и искажалась основная цель создания и функционирования в сфере оборонного ведомства лесохозяйственных подразделений. На момент создания в 1949 году, военные лесхозы обеспечивали организацию ведения образцового лесного 
хозяйства и восстановления лесов на землях обороны вокруг военных аэродромов, полигонов, арсеналов и тому подобное. Вместо этого, на данный момент основная цель деятельности лесохозяйственных субъектов хозяйствования, органом управления которых является Министерство обороны Украины, была сведена лишь к получению прибыли. Кроме того, злоупотребление должностными лицами разных уровней и бездействие оборонного ведомства, как органа управления имуществом, привели к безосновательному отчуждению земель и имущества, которыми лесохозяйственные подразделения наделялись при создании и в процессе функционирования. Безосновательность отчуждения имущества лесохозяйственных подразделений оборонного ведомства, по мнению автора, обусловлена особым статусом имущества военных лесхозов. Анализ национального законодательства показал, что с обретением Украиной независимости имущество учреждений и организаций, которые вошли в состав Вооруженных Сил Украины, получило статус военного имущества. А поэтому, отчуждение такого имущества невозможно без принятия правительством Украины соответствующих решений.

Также, по мнению автора, в сегодняшних реалиях, ведение лесного хозяйства на землях обороны должно быть организовано неприбыльными лесохозяйственными подразделениями из сферы управления Министерства обороны Украины.

Ключевые слова: лесное хозяйство, земли обороны, государственное предприятие, эффективное лесопользование, государственный контроль, леса обороны, военное имущество.

\title{
Problematic aspects of forest management on defense lands
}

\author{
Alexey Chernetsky * A; Anna Chernetskaya ${ }^{B}$ \\ ${ }^{*}$ Corresponding author: Territorial Department of Internal Audit of Military Units Directly Subordinated to the Ministry of Defense of Ukraine and \\ the General Staff of the Armed Forces of Ukraine, Senior Officer, e-mail: oleksiy.chernetskyi81@ukr.net \\ A Territorial Department of Internal Audit of Military Units Directly Subordinated to the Ministry of Defence of Ukraine and the General Staff of the \\ Armed Forces of Ukraine, 6, Povitroflotskyi Av., Kyiv-168, 03168, Ukraine \\ ${ }^{B}$ Military Institute of Taras Shevchenko National University of Kyiv, 81, Mykhailo Lomonosova, str., Kyiv, 03680, Ukraine
}

\begin{abstract}
The article considers the historical aspects and the current state of forest management on lands provided for defense purposes. The problems of the organization of forest management by the subjects of forestry activity, the governing body of which is the Ministry of Defense of Ukraine, are studied.

The analysis conducted by the author of the article allowed him to conclude that since 1991 the main purpose of the creation and operation in the field of defense of forestry units has been constantly changing and distorted. At the time of its establishment in 1949, military forestries provided for the organization of exemplary forestry and reproduction of forests on defense lands around military airfields, training grounds, military arsenals, etc. Instead, at present, the main purpose of forestry entities, the governing body of which is the Ministry of Defense of Ukraine, has been reduced to making a profit. In addition, the abuse of officials at various levels and the inaction of the Defense Ministry, as a property management body, led to the unjustified alienation of land and means of production, which forestry units were endowed with during the creation and operation. The groundlessness of the alienation of the property of forestry units of the Defense Ministry, according to the author, is due to the special status of the property of military forestries. The analysis of the national legislation showed that with the independence of Ukraine the property of the institutions and organizations that were part of the Armed Forces of Ukraine acquired the status of military property. Therefore, the alienation of such property is impossible without the adoption of appropriate decisions by the Government of Ukraine.
\end{abstract}


Also, according to the author, in today's realities forest management on defense lands should be organized by non-profit forestry units from the sphere of management of the Ministry of Defense of Ukraine.

Keywords: forestry, lands provided for defense, state enterprise, effective forest management, state control, forests of defense, military property.

\section{References}

1. Barsky Y., Polishchuk V. (2015) Financial incentives for sustainable development of forestry in the regions of Ukraine. Economic forum. № 1. P. 13 - 23. URL: http: //nbuv/gov.ua/UJRN/ecfor_2015_1_5.

2. Zamula H. (2013) The current state of forestry in Ukraine. Agrosvit. № 19. P. 54 - 59. URL: http: //nbuv/gov.ua/ UJRN / agrosvit_2013_19_12.

3. Kakhovich O., Tyuleneva G. Forestry. Current problems of the industry and ways to solve them. URL: http://rusnauka.com/21_NIEK_ 2007/Economics/24123/doc.htm

4. Mazurenok O. (2014) Economic significance of forests of Ukraine and strategy of their effective development. Scientific Bulletin of Kherson State University. Vip. 5. pp. 209-212.

5. Meshcherova A. The current state of forestry in Ukraine. Problems and prospects of development. URL: http://rusnauka.com/17_ AND_2010/Economics / 68627.doc.htm.

6. Regulations on the apartment maintenance service and apartment supply of the Soviet Army and Navy, approved by the order of the Minister of Defense of the USSR dated 22.02.1977 № 75.

7. Regulations on forestry and Regulations on forestry services of the Ministry of Defense of Ukraine, approved by the order of the Minister of Defence of Ukraine dated 21.01.1997 № 22.
8. Resolution of the Council of Ministers of the USSR "On the consolidation of forests by the Ministry of the Armed Forces of the USSR" from 19.04.1948 № 1264478p.

9. The procedure for forestry in the forests assigned to the Ministry of Defense of the USSR, approved by the order of the Council of Ministers of the USSR from 17.09.1965 № 1869RS.

10. On the use of defense lands: Law of Ukraine of November 27, 2003 № 1345-IV.

11. Forest Code of Ukraine, enacted by the Resolution of the Verkhovna Rada of Ukraine of 21.01.1994 № 3853-XI.

12. Land Code of the Ukrainian Soviet Socialist Republic of 18.12.1990.

13. Regulations on the procedure for forestry in forests assigned to the Ministry of Defense of the USSR, and Regulations on forestry bodies of the Ministry of Defense of the USSR, approved by the order of the Minister of Defense of the USSR from 08.07.1966 № 161;

14. Resolution of the Government of the Russian Federation of 02.02.1998 № 135 "On consolidation of forests located on defense lands by the federal executive body on defense issues". 